\title{
Cause of death in Washington state veterans hospitalized with acute coronary syndromes in the veterans health administration Charles Maynard ${ }^{* 1,2}$, Elliott Lowy ${ }^{1,2}$, Mary McDonell ${ }^{1}$ and Stephan D Fihn $1,2,3$
}

\author{
Address: ${ }^{1}$ Department of Veterans Affairs Puget Sound Health Care System, Seattle, WA, USA, ${ }^{2}$ Department of Health Services, University of \\ Washington, Seattle, WA, USA and ${ }^{3}$ Department of Medicine, University of Washington, Seattle, WA, USA \\ Email: Charles Maynard* - cmaynard@u.washington.edu; Elliott Lowy - Elliott.Lowy@va.gov; Mary McDonell - Mary.Mcdonell@va.gov; \\ Stephan D Fihn - Stephan.Fihn@va.gov \\ * Corresponding author
}

Published: 23 July 2008

Population Health Metrics 2008, 6:3 doi:10.1 186/1478-7954-6-3
Received: 17 January 2008

Accepted: 23 July 2008

This article is available from: http://www.pophealthmetrics.com/content/6/1/3

(c) 2008 Maynard et al; licensee BioMed Central Ltd.

This is an Open Access article distributed under the terms of the Creative Commons Attribution License (http://creativecommons.org/licenses/by/2.0), which permits unrestricted use, distribution, and reproduction in any medium, provided the original work is properly cited.

\begin{abstract}
Background: In the United States, relatively little is known about cause of death in individuals who die prior to or after hospital discharge for acute coronary syndromes (ACS). The purpose of this report was to compare baseline patient characteristics according to whether the underlying cause of death was cardiac or non-cardiac.

Methods: We linked cause of death information from Washington State death records to the Department of Veterans Affairs (VA) External Peer Review Program ACS registry. From 524 individuals who were hospitalized for ACS in veterans hospitals located in Washington State or Oregon, we identified 136 individuals who according to VA death records died during the years 2003 to 2005. Of these, 117 (86\%) were found in Washington State death records. Sociodemographic variables, as well as underlying and secondary causes of death, were obtained from Washington State death records provided by the Washington State Department of Health. Clinical variables, including medical histories, presentation on admission, and in-hospital death were extracted from the VA ACS registry.
\end{abstract}

Results: Somewhat surprisingly, only $52 \%$ of veterans died of cardiac causes when only the underlying cause of death was used. However, when secondary causes of death were added to the definition, the proportion that died of cardiac causes increased to $81 \%$. Patient characteristics were similar in the two groups, although small numbers limited the ability to detect statistically significant differences.

Conclusion: These preliminary findings suggest that it is important to consider secondary causes as well as the underlying one when classifying deaths as cardiac or non-cardiac.

\section{Background}

In the United States, relatively little is known about cause of death in individuals who die prior to or after hospital discharge for acute coronary syndromes (ACS). Many large registries such as the National Registry of Myocardial Infarction do not collect information on patients after hospitalization for ACS, nor do they collect information regarding the circumstances of death occurring in the hos- 
pital. The situation in Europe is somewhat different in that it is possible to link national vital status registers with disease based registries [1,2]. The National Death Index in the United States is a means for ascertaining vital status and cause of death, but search charges can be expensive for disease registries with large numbers of patients [3]. The Department of Veterans Affairs (VA) devotes considerable resources to chart abstraction for patients hospitalized with ACS and also has a vital status register that does not contain cause of death information $[4,5]$. The major objective of this report was to compare baseline patient characteristics according to whether the underlying cause of death was cardiac or non-cardiac. This was accomplished by linking cause of death information from Washington State death records to the VA External Peer Review Program ACS registry.

\section{Methods \\ Patient population}

Between October 2003 and December 2005, there were 524 individuals who were admitted to VA hospitals located in Washington State or Oregon and had a diagnosis of acute myocardial infarction or unstable angina. These individuals were Washington State residents (identified by residential zip code) admitted to VA hospitals or were non-state residents admitted to 1 of 3 VA hospitals in Washington State. According to VA death records, 136 (26\%) died prior to January 1, 2006. Using the social security number, full patient name, and date of birth, these records were linked to death records obtained from the Washington State Department of Health. This process identified 117 (86\%) decedents in state death records. Of the 19 who were not found, 8 were Washington State residents, 6 were residents of Idaho, 3 - of Alaska, 1 - of Montana, and 1 - of Oregon. Individuals with missing death records were similar to those whose death records were found in that the two groups did not differ with respect to age, gender, race, or year of death.

\section{Study variables}

Sociodemographic variables in this study were obtained from Washington State death records and included age, gender, race, education, marital status, tobacco use as contributing to death, underlying and secondary causes of death, for which there were up to 20 codes. Cause of death was categorized as cardiac or non-cardiac, and International Classification of Diseases $10^{\text {th }}$ Revision (ICD-10) codes were used to classify cause of death. The following ranges of ICD-10 codes were used to identify cardiac causes: I10 - I15 (hypertensive disease), I20 - I25 (ischemic heart disease), and I30 - I52 (other forms of heart disease). Cause of death classified as cardiac or noncardiac was defined in two ways; first, only the underlying cause of death was considered, and second, both underlying and secondary ICD-10 codes were used. Variable col- lection for the External Peer Review Program database has been described in detail [4]. Using this database we determined the type of ACS (defined as ST elevation myocardial infarction, non ST elevation myocardial infarction, or unstable angina) and whether the patient died in the hospital. Numerous other patient characteristics were collected, including heart failure, prior coronary artery bypass graft surgery, lipid disorder, diabetes mellitus, tobacco use, dementia, and cerebrovascular, chronic obstructive pulmonary, and renal diseases. Cardiac medications prescribed at admission were also recorded. This study was approved as by the University of Washington Human Subjects Review Board. A waiver of informed consent was granted.

\section{Statistical methods}

For comparing differences between the cardiac and noncardiac groups, the 2 sample t-test was used for continuous variables and the Chi-square statistic - for categorical variables.

\section{Results}

The distribution of underlying cause of death is presented in table $1 ; 52 \%$ of deaths were due to cardiac causes of which over $90 \%$ were due to ischemic conditions. Individuals in this study can be characterized as older white men, $32 \%$ of whom did not graduate from high school (Table 2). A higher proportion of the non-cardiac group included African-American veterans, but for the most part sociodemographic characteristics were similar in the two groups. Of the 7 African-Americans, 1 (14\%) died of a car-

Table I: Distribution of underlying cause of death $(n=1$ I $)$

\begin{tabular}{lr}
\hline Cause & $\mathrm{n}(\%)$ \\
\hline Non-cardiac & $56(48 \%)$ \\
Infection & $4(3 \%)$ \\
Cancer & $18(15 \%)$ \\
Diabetes & $4(3 \%)$ \\
Dementia & $1(<1 \%)$ \\
Polyneuropathy & $1(<1 \%)$ \\
Stroke & $2(2 \%)$ \\
Vascular & $2(2 \%)$ \\
Pulmonary & $10(8 \%)$ \\
Gastric & $4(3 \%)$ \\
Decubitus ulcer & $1(<1 \%)$ \\
Renal & $7(6 \%)$ \\
Accident & $2(2 \%)$ \\
Cardiac & $61(52 \%)$ \\
Hypertension & $1(<1 \%)$ \\
Acute myocardial infarction & $23(20 \%)$ \\
Atherosclerotic cardiovascular disease & $32(27 \%)$ \\
Other ischemic heart disease & $2(2 \%)$ \\
Atrial fibrillation & $1(<1 \%)$ \\
Cardiomyopathy & $1(<1 \%)$ \\
Congestive heart failure & $1(<1 \%)$ \\
&
\end{tabular}


Table 2: Socio-demographic characteristics of decedents according to underlying cause of death

\begin{tabular}{|c|c|c|c|c|}
\hline Characteristic & $\begin{array}{l}\text { Cardiac } \\
(\mathrm{n}=61)\end{array}$ & $\begin{array}{l}\text { Non-cardiac } \\
(\mathrm{n}=56)\end{array}$ & $\begin{array}{c}\text { Total } \\
(n=117)\end{array}$ & $P$ \\
\hline Year of death & & & & 0.86 \\
\hline 2003 & $7 \%$ & $5 \%$ & $6 \%$ & \\
\hline 2004 & $39 \%$ & $36 \%$ & $38 \%$ & \\
\hline 2005 & $54 \%$ & $59 \%$ & $56 \%$ & \\
\hline Age (yrs) & $74 \pm 10$ & $76 \pm 9$ & $75 \pm 10$ & 0.18 \\
\hline Men & $97 \%$ & $95 \%$ & $96 \%$ & \\
\hline Race & & & & 0.033 \\
\hline White & $93 \%$ & $89 \%$ & $92 \%$ & \\
\hline African-American & $2 \%$ & $11 \%$ & $6 \%$ & \\
\hline Other & $5 \%$ & $0 \%$ & $2 \%$ & \\
\hline Marital status & & & & 0.38 \\
\hline Never & $13 \%$ & $9 \%$ & $11 \%$ & \\
\hline Married & $51 \%$ & $43 \%$ & $47 \%$ & \\
\hline Widowed & $23 \%$ & $23 \%$ & $23 \%$ & \\
\hline Divorced & $13 \%$ & $25 \%$ & $19 \%$ & \\
\hline Education & & & & 0.07 \\
\hline$<12$ years & $21 \%$ & $43 \%$ & $32 \%$ & \\
\hline High school graduate & $46 \%$ & $39 \%$ & $43 \%$ & \\
\hline Some college & $21 \%$ & $12 \%$ & $17 \%$ & \\
\hline College graduate & $12 \%$ & $5 \%$ & $8 \%$ & \\
\hline Did tobacco use contribute to death? & & & & 0.23 \\
\hline Yes & $26 \%$ & $14 \%$ & $20 \%$ & \\
\hline No & $23 \%$ & $36 \%$ & $29 \%$ & \\
\hline Probably & $12 \%$ & $7 \%$ & $9 \%$ & \\
\hline Unknown & $11 \%$ & $43 \%$ & $41 \%$ & \\
\hline
\end{tabular}

Table 3: Clinical characteristics of decedents according to underlying cause of death

\begin{tabular}{|c|c|c|c|c|}
\hline Characteristic & $\begin{array}{l}\text { Cardiac } \\
(\mathrm{n}=61)\end{array}$ & $\begin{array}{l}\text { Non-cardiac } \\
(n=56)\end{array}$ & $\begin{array}{c}\text { Total } \\
(n=117)\end{array}$ & $P$ \\
\hline \multicolumn{5}{|l|}{ History of } \\
\hline Congestive heart failure & $52 \%$ & $48 \%$ & $50 \%$ & 0.26 \\
\hline Coronary artery bypass graft surgery & $28 \%$ & $16 \%$ & $22 \%$ & 0.12 \\
\hline Myocardial infarction & $41 \%$ & $30 \%$ & $36 \%$ & 0.23 \\
\hline Lipid disorder & $57 \%$ & $50 \%$ & $54 \%$ & 0.42 \\
\hline Cerebrovascular disease & $3 \%$ & $16 \%$ & $9 \%$ & 0.018 \\
\hline Chronic obstructive pulmonary disease & $28 \%$ & $41 \%$ & $34 \%$ & 0.13 \\
\hline Diabetes mellitus & $23 \%$ & $16 \%$ & $20 \%$ & 0.35 \\
\hline Renal disease & $15 \%$ & $18 \%$ & $16 \%$ & 0.65 \\
\hline Tobacco use & $50 \%$ & $39 \%$ & $44 \%$ & 0.44 \\
\hline Dementia & $20 \%$ & $29 \%$ & $24 \%$ & 0.26 \\
\hline \multicolumn{5}{|l|}{ Medications } \\
\hline Angiotensin converting enzyme inhibitor & $57 \%$ & $45 \%$ & $51 \%$ & 0.17 \\
\hline Aspirin & $57 \%$ & $52 \%$ & $55 \%$ & 0.54 \\
\hline Beta-blockers & $62 \%$ & $46 \%$ & $55 \%$ & 0.08 \\
\hline Lipid lowering & $62 \%$ & $45 \%$ & $54 \%$ & 0.056 \\
\hline Platelet inhibitors & $15 \%$ & $20 \%$ & $17 \%$ & 0.48 \\
\hline Type of acute coronary syndrome & & & & 0.17 \\
\hline Unstable angina & $7 \%$ & $4 \%$ & $5 \%$ & \\
\hline Non ST elevation myocardial infarction & $78 \%$ & $91 \%$ & $85 \%$ & \\
\hline ST elevation myocardial infarction & $15 \%$ & $5 \%$ & $10 \%$ & \\
\hline In-hospital death & $26 \%$ & $30 \%$ & $28 \%$ & 0.62 \\
\hline
\end{tabular}


Table 4: Socio-demographic characteristics of decedents according to underlying and secondary causes of death

\begin{tabular}{|c|c|c|c|c|}
\hline Characteristic & $\begin{array}{l}\text { Cardiac } \\
(\mathrm{n}=95)\end{array}$ & $\begin{array}{c}\text { Non-cardiac } \\
(\mathrm{n}=22)\end{array}$ & $\begin{array}{c}\text { Total } \\
(n=117)\end{array}$ & $P$ \\
\hline Year of death & & & & 0.79 \\
\hline 2003 & $5 \%$ & $9 \%$ & $6 \%$ & \\
\hline 2004 & $38 \%$ & $36 \%$ & $38 \%$ & \\
\hline 2005 & $57 \%$ & $55 \%$ & $56 \%$ & \\
\hline Age (yrs) & $74 \pm 10$ & $77 \pm 10$ & $75 \pm 10$ & 0.22 \\
\hline Men & $96 \%$ & $96 \%$ & $96 \%$ & 0.94 \\
\hline Race & & & & 0.18 \\
\hline White & $93 \%$ & $86 \%$ & $92 \%$ & \\
\hline African-American & $4 \%$ & $14 \%$ & $6 \%$ & \\
\hline Other & $3 \%$ & $0 \%$ & $2 \%$ & \\
\hline Marital status & & & & 0.23 \\
\hline Never & $14 \%$ & $0 \%$ & $11 \%$ & \\
\hline Married & $47 \%$ & $46 \%$ & $47 \%$ & \\
\hline Widowed & $22 \%$ & $27 \%$ & $23 \%$ & \\
\hline Divorced & $17 \%$ & $27 \%$ & $19 \%$ & \\
\hline Education & & & & 0.006 \\
\hline$<12$ years & $26 \%$ & $54 \%$ & $32 \%$ & \\
\hline High school graduate & $48 \%$ & $18 \%$ & $43 \%$ & \\
\hline Some college & $15 \%$ & $27 \%$ & $17 \%$ & \\
\hline College graduate & $11 \%$ & $0 \%$ & $8 \%$ & \\
\hline Did tobacco use contribute to death? & & & & 0.49 \\
\hline Yes & $22 \%$ & $14 \%$ & $20 \%$ & \\
\hline No & $26 \%$ & $41 \%$ & $29 \%$ & \\
\hline Probably & $10 \%$ & $9 \%$ & $9 \%$ & \\
\hline Unknown & $37 \%$ & $27 \%$ & $41 \%$ & \\
\hline
\end{tabular}

Table 5: Clinical characteristics of decedents according to underlying and secondary causes of death

\begin{tabular}{|c|c|c|c|c|}
\hline Characteristic & $\begin{array}{l}\text { Cardiac } \\
(\mathrm{n}=95)\end{array}$ & $\begin{array}{l}\text { Non-cardiac } \\
(\mathrm{n}=22)\end{array}$ & $\begin{array}{c}\text { Total } \\
(n=117)\end{array}$ & $P$ \\
\hline \multicolumn{5}{|l|}{ History of } \\
\hline Congestive heart failure & $50 \%$ & $54 \%$ & $50 \%$ & 0.67 \\
\hline Coronary artery bypass graft surgery & $24 \%$ & $14 \%$ & $22 \%$ & 0.28 \\
\hline Myocardial infarction & $38 \%$ & $27 \%$ & $36 \%$ & 0.35 \\
\hline Lipid disorder & $56 \%$ & $46 \%$ & $54 \%$ & 0.38 \\
\hline Cerebrovascular disease & $10 \%$ & $9 \%$ & $9 \%$ & 0.96 \\
\hline Chronic obstructive pulmonary disease & $35 \%$ & $32 \%$ & $34 \%$ & 0.80 \\
\hline Diabetes mellitus & $22 \%$ & $9 \%$ & $20 \%$ & 0.17 \\
\hline Renal disease & $16 \%$ & $18 \%$ & $16 \%$ & 0.78 \\
\hline Tobacco use & $44 \%$ & $46 \%$ & $44 \%$ & 0.93 \\
\hline Dementia & $22 \%$ & $32 \%$ & $24 \%$ & 0.34 \\
\hline \multicolumn{5}{|l|}{ Medications } \\
\hline Angiotensin converting enzyme inhibitor & $52 \%$ & $50 \%$ & $51 \%$ & 0.89 \\
\hline Aspirin & $56 \%$ & $50 \%$ & $55 \%$ & 0.62 \\
\hline Beta-blockers & $57 \%$ & $46 \%$ & $55 \%$ & 0.33 \\
\hline Lipid lowering & $56 \%$ & $46 \%$ & $54 \%$ & 0.38 \\
\hline Platelet inhibitors & $17 \%$ & $18 \%$ & $17 \%$ & 0.88 \\
\hline Type of acute coronary syndrome & & & & 0.27 \\
\hline Unstable angina & $6 \%$ & $0 \%$ & $5 \%$ & \\
\hline Non ST elevation myocardial infarction & $82 \%$ & $96 \%$ & $85 \%$ & \\
\hline ST elevation myocardial infarction & $12 \%$ & $4 \%$ & $10 \%$ & \\
\hline In-hospital death & $30 \%$ & $23 \%$ & $28 \%$ & 0.53 \\
\hline
\end{tabular}


diac cause, whereas over half of 100 white patients did. Clinical characteristics in the two groups were similar with the exception that a higher proportion of the non-cardiac group included individuals with a history of cerebrovascular disease (Table 3 ). Of the 11 individuals with a history of cerebrovascular disease, $2(18 \%)$ died of cardiac causes, whereas $56 \%$ of those without a history of cerebrovascular disease died of cardiac causes.

When secondary ICD-10 codes were considered, the number of deaths due to cardiac causes increased by $39 \%$, from 61 to 95, and the percent with death due to cardiac causes rose to $81 \%$. In 34 individuals with only a secondary diagnosis of cardiac disease, the underlying causes of death were cancer $(26 \%)$, respiratory $(20 \%)$, genitourinary, including renal $(12 \%)$, vascular, including cerebrovascular $(12 \%)$, diabetes $(9 \%)$, digestive $(9 \%)$, and other $(12 \%)$ including bacterial, mental, and accidental. For both demographic and clinical characteristics, the 2 groups were similar, although the level of education was higher in the cardiac group and there were proportionally more African-Americans in the non-cardiac group (Tables 4 and 5).

\section{Discussion}

It was somewhat surprising that only about half of the individuals hospitalized for ACS died of cardiac causes when only the underlying cause of death was used to identify cardiac deaths. However, when secondary causes were included in the definition, over $80 \%$ of deaths were due to cardiac conditions. This result seems more reasonable given that decedents had significant cardiovascular disease and were hospitalized for either acute myocardial infarction or unstable angina pectoris. The findings that there were proportionally more African-Americans as well as lower levels of education in both non-cardiac groups are intriguing and need further investigation. There were, however, only seven African-Americans in the study. The ability to detect statistically significant differences was limited by small numbers of deaths.

This study also demonstrated that it was possible to link state death records with the VA ACS database, although we were unable to find Washington State death records for 19 individuals ( 8 Washington State residents, 11 non residents) who were deceased according to VA records. In theory, Washington State death records include all deceased residents, even those who died out of state, and may include non-state residents who died in the state. In practice, this may be quite different as states have varying reciprocal reporting arrangements. It is also possible that reporting of deaths was delayed, and that some of these missing deaths may appear in subsequent annual updates provided by the state, although this was not the case in 2006. We did not have the time or resources to contact neighboring states to determine the vital status of the 11 non-Washington State residents whose death records were not found.

In general, cause of death information, despite its inherent limitations, is potentially useful to researchers, managers, and policy makers [6]. There are long standing concerns about the accuracy of this information as well as about who determines the cause of death. However, a recent study reported that Washington State veterans who used VA health care were more likely to die of alcohol and/or drug related causes than veterans who did not use VA health care [7]. While such information may be of value, it can be difficult to obtain. The United States National Center for Health Statistics does support the National Death Index, which along with the Social Security Death Master File, are the major methods of mortality ascertainment in the United States [3]. The National Death Index, however, is the only national source of cause of death information in the United States and is available only for research purposes. Only a small number of states such as Washington make their death records available to researchers.

\section{Conclusion}

In the future, we expect that more relevant findings will be generated as deaths accrue in Washington State veterans with ACS. We also hope to use the National Death Index for further investigation. These preliminary findings suggest that it is important to consider secondary causes as well as the underlying one when classifying deaths as cardiac or non-cardiac.

\section{Competing interests}

The authors declare that they have no competing interests.

\section{Authors' contributions}

CM assumed responsibility for study design, conception, data acquisition, analysis and interpretation, drafted the manuscript, critically revised it for important intellectual content, and approved the final version. EL, MM, and SDF were responsible for data acquisition, analysis and interpretation, critically revised the paper for important intellectual content, and approved the final version of manuscript.

\section{Acknowledgements}

This work was supported by a grant from the Department of Veterans Affairs Quality Enhancement Research Initiative. The views expressed in this article are those of the authors and do not necessarily represent the views of the Department of Veterans Affairs.

\section{References}

I. Hammar N, Alfredsson L, Rosen M, Spetz CL, Kahan T, Ysberg AS: A national record linkage to study acute myocardial infarction incidence and case fatality in Sweden. Int J Epidemiol 200I, 30:S30-S34. 
2. Mahonen M, Salomaa $\mathrm{V}$, Torppa J, Miettinen $\mathrm{H}$, Pyorala K, ImmonenRaiha P, Niemela M, Ketonen M, Arstila E, Lehto S, Mustaniemi H, Palomaki P, Puska P, Vuorenmaa T, Tuomilehto J: The validity of the routine mortality statistics on coronary heart disease in Finland: Comparison with the FINMONICA MI Register data for the years 1983-1992. J Clin Epidemiol 1999, 52:157-I66.

3. Cowper DC, Kubal JD, Maynard C, Hynes DM: A primer and comparative review of major US mortality databases. Ann Epidemiol 2002, I 2:462-468.

4. Maynard C, Lowy E, Rumsfeld J, Sales AE, Sun H, Kopjar B, Fleming B, Jessee RL, Rusch R, Fihn SD: The prevalence and outcomes of inhospital acute myocardial infarction in the department of veterans affairs health system. Arch Intern Med 2006, 166:1410-1416.

5. Sohn MW, Arnold N, Maynard C, Hynes D: Accuracy and completeness of mortality data in the department of veterans affairs. Pop Hlth Metric 2006, 4:2 [http://www.pophealthmet rics.com/content $/ 4 / 1 / 2]$.

6. Byass P: Who needs cause-of-death data? PLoS Med 2007, 4:e333. doi: I0.37|/journal.pmed.0040333

7. Maynard C, Boyko E): Differences in cause of death between Washington State veterans who did and did not use VA health care services. J Rehabil Research Devel 2006, 43:825-830.

Publish with Bio Med Central and every scientist can read your work free of charge

"BioMed Central will be the most significant development for disseminating the results of biomedical research in our lifetime. "

Sir Paul Nurse, Cancer Research UK

Your research papers will be:

- available free of charge to the entire biomedical community

- peer reviewed and published immediately upon acceptance

- cited in PubMed and archived on PubMed Central

- yours - you keep the copyright 